\begin{tabular}{ll}
\hline \hline MINING AND METALLURGY INSTITUTE BOR & ISSN: 2334-8836 \\
& UDC: 622 \\
\hline \hline
\end{tabular}

\title{
CONDUCTING THE CONTROLLED MASS BLASTING ON THE LIMESTONE MINE BREZA, BREZA, WITH USE THE ANFO EXPLOSIVES "RUDEX - 1"
}

\section{Abstract}

ANFO explosives in most cases account for $90 \%$ of the total weight of explosives during the execution of mass mining in the mining facilities on the territory of Bosnia and Herzegovina. A large number of domestic drilling-blasting companies use ANFO explosives of own production (production of "in situ", i.e. with mobile plant at the site of use). This paper deals with the experiences of "RUDEX" Ltd-Sarajevo, in the design and execution of mass-drill and mining in the limestone quarry "RKB" with the dominant use of ANFO explosives (RUDEX-1).

Keywords: Mining, ANFO, quarry RKB, drilling-mining parameters

\section{INTRODUCTION}

On the limestone deposit "Nedici", Economic Society "Limestone mine Breza" p.l.c. Breza, conducts the exploitation of the construction limestone from 2000. The deposit is open on the right bank of the river Stavnja within $2 \mathrm{~km}$ northeast of Breza and $27 \mathrm{~km}$ from Sarajevo, adjacent to the traffic line: SarajevoBreza-Vares. A limited research and exploitation area extends by the right slope of Stavnja, referred to as a Good side of the North-South direction.

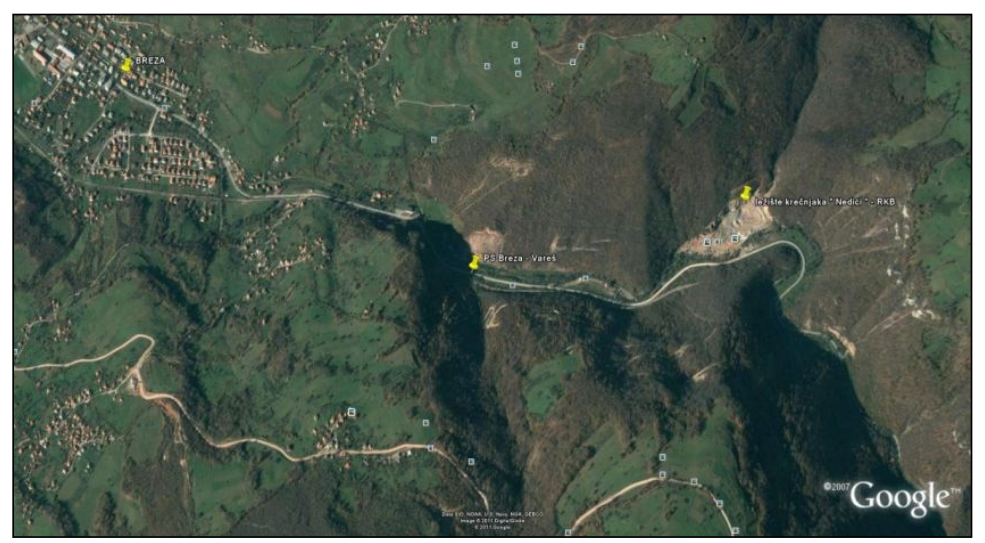

Figure 1 Geographical deposit position of "Nedici" - RKB (LMB) Ltd, Breza

\footnotetext{
* "RUDEX" Ltd Sarajevo, BiH

** „STUDENTSKI BIRO 99“ Ltd Tuzla, BiH

***”" "INZIO" Ltd., Tuzla, BiH
} 
Limestone deposits belong to this classic gray sedimentary carbonate layered and banky rocks, and in a petrographic sense it is a calcarenite with $\mathrm{CaCO}_{3}$ content of $95 \%$, bulk density $(\gamma)$ of the limestone ranges about $2800 \mathrm{~kg} / \mathrm{m}^{3}$ q.m. The compressive strength of the samples tested in the dry state is about $160 \mathrm{MPa}$, while the compressive strength of the samples tested in a watersaturated state is around $133 \mathrm{MPa}$.

\section{MINING PARAMETERS ON THE LIMESTONE MINE BREZA}

Major mining project of the limestone exploitation defines drill-mining parameters as follows:

- blast hole drilling diameter $(\varnothing)$ $-76 \mathrm{~mm}$,
- floor height $h=10 \mathrm{~m}$ ' optimal footprint of blast stone $600 \mathrm{~mm}$,

- the least resistance line $(\mathrm{N}) 2.7 \mathrm{~m}$, the distance between the wells in row (a) $3.5 \mathrm{~m}$,

- distance between the rows of bores (b) $3.2 \mathrm{~m}, 2.7 \mathrm{~m}$ length of slug',

- specific explosive expenditure (q) $0.34 \mathrm{~kg} / \mathrm{m}^{3}$ q.m.,

- percentage of the initial plastic blast explosives around 5\%, percentage of ANFO explosives in blasting is about $95 \%$,

- total quantity of explosives per borehole $30.5 \mathrm{~kg}$,

- maximum defined quantity of explosives per minefield is $1,000 \mathrm{~kg}$, with recommendation of using the millisecond retarders.

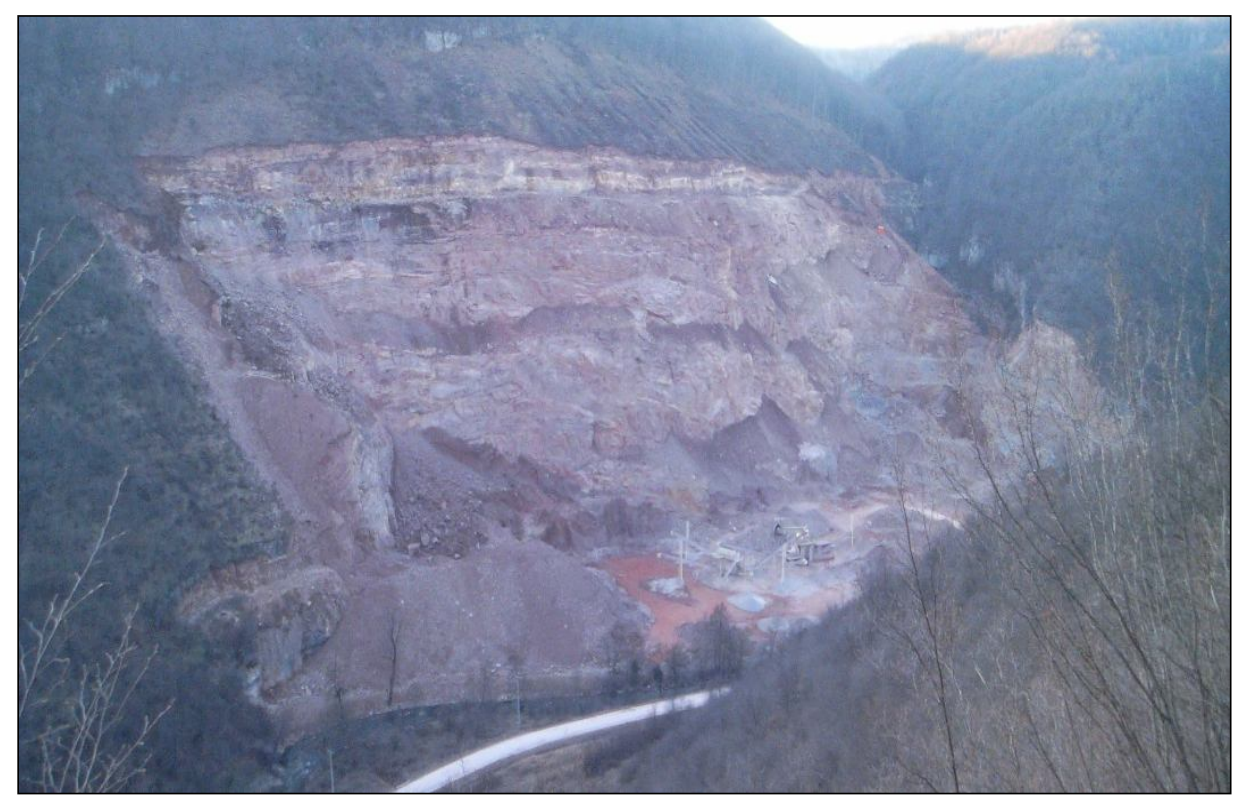

Figure 2 View of the terrain and limestone quarry "Nedici" in the valley of Stavnja

During blasting process, the certain types of produced energies can be generally classified into: a) useful energies, and

b) useless energies 


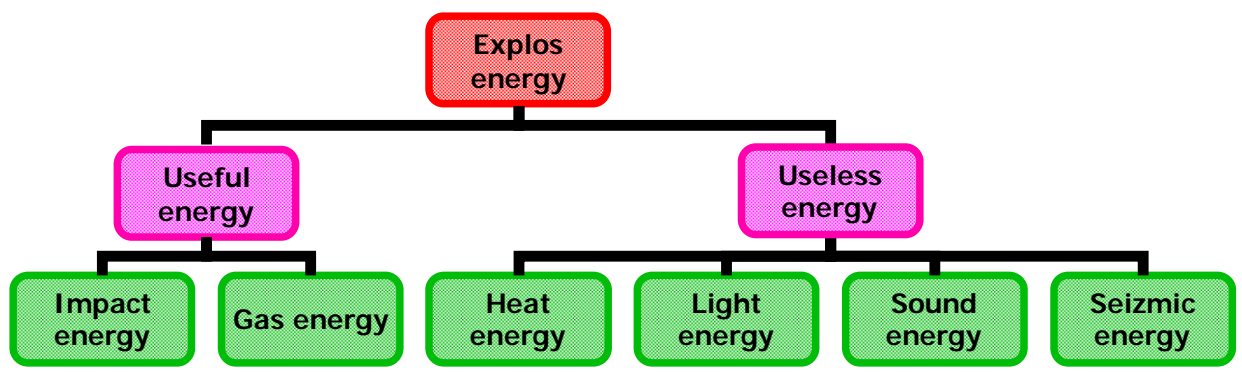

Figure 3 Schematic view of several types of energies generated by the explosion process

There are two useful types of energies generated by chemical reaction of explosion decomposition with useful complete work as the result.

\section{The first type of energy is referred to as the impact energy}

During the chemical decomposition of explosives and its detonation a strong pressure is created which manifests itself in the impact energy on the rock mass. Pressure caused by detonation of operational explosives density duplicated by square velocity of explosives reaction, which makes a form of kinetic energy. Detonation pressure is the pressure made by spreading the detonation wave through the column of explosives. Detonation pressure will be maximized in the explosives cartridge on the opposite end of its initiation. Detonation pressure on the cartridge is nearly zero because the detonation wave does not spread to the edges of cartridge.

\section{The second type of energy is called the energy of gas}

Energy gas is released during the process of detonation and causes much of rock fracturing in mining of closed blast holes. Therefore a definition of optimum length of cap mine blast holes and selection of suitable inert material to form a cap are very important in mining. Gas pressure, often called the explosion pressure, is pressure on the walls of borehole made by expanding gases after chemical reaction completition. Size explosion pressure depends on the volume of gas released per unit weight of explosive and quantity of heat that is released during the reaction.

\section{The third type of energy is called a useless energy}

As its name suggests, that is the result of obtaining the negative byproducts in development of chemical reactions or decomposition of explosives: heat energy, light energy, sound energy and seismic energy - seismic effects on objects and living beings in the immediate vicinity of blasting activities.

\section{EXPLOSIVE CONSTITUENTS IN EXPLOSIVES}

Appropriate relations of explosive constituents in explosives are the basis for a successful implementation - quality chemical reactions in explosives, which consequently should provide maximum extent of possible degradation, primarily in the same impact energy and gas energy as a kinetic energy, and minimum percentage of the useless energy production: heat, light, sound and seismic energy. Building blocks of explosives are generally considered as the elements of fuel or oxidizing elements and they are shown in the following table: 
Table 1 Constituent elements in explosives

\begin{tabular}{|c|c|c|}
\hline Ingredient & Chemical formula & Function \\
\hline \hline Nitroglycerin & $\mathrm{C}_{3} \mathrm{H}_{5} \mathrm{O}_{9} \mathrm{~N}_{3}$ & explosive basis \\
\hline Nitrocellulose & $\mathrm{C}_{6} \mathrm{H}_{7} \mathrm{O}_{11} \mathrm{~N}_{3}$ & explosive basis \\
\hline Trinitrotoluol (TNT) & $\mathrm{C}_{7} \mathrm{H}_{5} \mathrm{O}_{6} \mathrm{~N}_{3}$ & explosive basis \\
\hline Ammonium nitrate & $\mathrm{H}_{4} \mathrm{O}_{3} \mathrm{~N}_{2}$ & oxygen carrier \\
\hline Natrium nitrate & $\mathrm{NaNO}_{3}$ & oxygen carrier \\
\hline Oil & $\mathrm{CH}_{3}$ & fuel \\
\hline Wood pulp & $\mathrm{C}_{6} \mathrm{H}_{10} \mathrm{O}_{5}$ & fuel \\
\hline Carbon & $\mathrm{C}$ & fuel booster \\
\hline Aluminum powder & $\mathrm{Al}$ & acid neutralizer \\
\hline Limestone-chalk & $\mathrm{CaCO}$ & acid neutralizer \\
\hline Zinc oxide & $\mathrm{ZnO}$ & suppresses flames \\
\hline Natrium chloride & $\mathrm{NaCl}$ & \\
\hline
\end{tabular}

Almost all of the explosives use oxygen as the oxidizing element. The Ideal Gases Law can be used as the first approximation to determine the pressure generated in the reaction of explosives:

$$
P \cdot V=N \cdot R \cdot T
$$

wherein:

$$
\begin{aligned}
& \mathrm{N}=\text { gas molecules } \\
& \mathrm{P}=\text { pressure } \\
& \mathrm{V}=\text { volume } \\
& \mathrm{R}=\text { gas constant and } \\
& \mathrm{T}=\text { absolute temperature }
\end{aligned}
$$

Explosive reactions do not behave ideally, as assumed by this equation, because of extremely high pressures, and must use the correction factors for the assumed behavior of gases at high pressures. Probably, the easiest way to understand and use of a correction factor is the use of formula:

$$
P \cdot V=C \cdot N \cdot R \cdot T
$$

wherein:

$\mathrm{C}=$ compressibility factor

Compressibility factor (C) is obtained from curve, which requires knowledge of reduced temperature and reduced pressure which comes from natural gas. For production of explosives, a great attention is paid to balancing the fuel and oxygen in order to avoid oxygen shortage and excess. Lack of oxygen would lead to low energy release, slow release of energy, a difference in number of small molecules to lower temperature and thus to lower pressure. Oxygen excess would lead to an extreme sensitivity, less energy release and creating harmful and toxic nitrogen oxides $\mathrm{N}_{2} \mathrm{O}_{5}, \mathrm{~N}_{2} \mathrm{O}_{3}, \mathrm{NO}_{2}$, $\mathrm{N}_{2} \mathrm{O}$, NO. Ammonium nitrate (AN) has the formula $\mathrm{NH}_{4} \mathrm{NO}_{3}$ showing the ingredients and their relationship. Writing the formula otherwise generates $\mathrm{N}_{2} \mathrm{H}_{2} \mathrm{O}_{3}$, in the form of the following tables:

Table 2 Balance of fuel and oxygen

\begin{tabular}{|c|c|c|}
\hline \hline Element & Desired reaction product & Oxygen required \\
\hline \hline $\mathrm{N}_{2}$ & $\mathrm{~N}_{2}$ & None \\
\hline $\mathrm{H}_{4}$ & $2 \mathrm{H}_{2} \mathrm{O}$ & 2 \\
\hline $\mathrm{O}_{3}$ & None & None \\
\hline
\end{tabular}

lack or excess $3-2=1$ (oxygen excess) 
Oil is added to AN to provide the necessary fuel. Oil (FO) for these pur- poses may have the formula $\mathrm{CH}_{2}$. If $\mathrm{CH}_{2}$ is written in the form of table:

Table 3 Chemical oxidation reaction

\begin{tabular}{|c|c|c||}
\hline Element & Desired reaction product & Oxygen required \\
\hline \hline $\mathrm{C}$ & $\mathrm{CO}_{2}$ & 2 \\
\hline $\mathrm{H}_{2}$ & $\mathrm{H}_{2} \mathrm{O}$ & 1 \\
\hline
\end{tabular}

Zero (0) - 3 (the lack of oxygen)

The result is a lack of oxygen per unit of $\mathrm{CH}_{2}$. Because $\mathrm{AN}$ has one oxygen it takes three units of AN to balance one unit of the ANFO mixture.

$$
3 \mathrm{AN}+1 \mathrm{FO} \mathrm{CO}_{2}+7 \mathrm{H}_{2} \mathrm{O}+3 \mathrm{~N}_{2}
$$

This balanced reaction shows that the required three molecular weight nitrate and one molecular weight of oil is needed to produce an ideal gas which was previously discussed, to produce a lucrative work demolition of rock. The following Figure gives the ratio of energy loss ammonium nitrate and oil according to the percentage of oil that is added to the amalgam. Theoretically, optimum balance is $5.7 \%$ oil and 94.3 $\%$ nitrate. Manufacturers normally make an amalgam with $6 \%$ oil. The following Figure illustrates that when the oil content decreases below the required $5.7 \%$, the energy release rapidly declines. If the equipment that constitutes the mixture of oil and nitrate is not accurate, it is always better to have more oil than less, because of its evaporation.

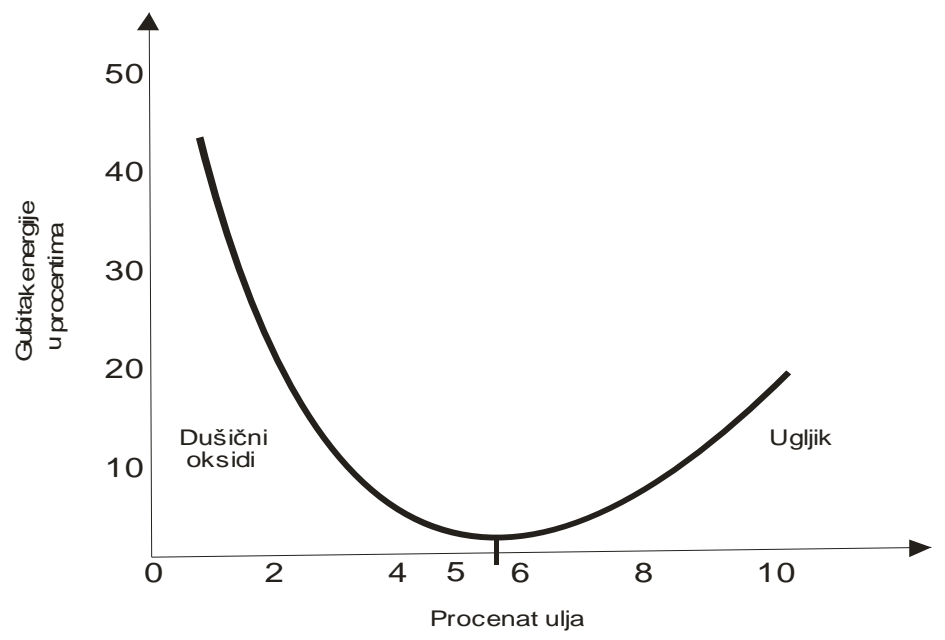

Figure 4 Dependence of energy loss by percentage share of oil in ANFO explosives

\section{Production and use of ANFO explosives}

ANFO explosives or ANFO amalgams are nothing new or spectacular, even in the region of Southeast Europe, given their chemical composition and its facility of production, because in the mining practice they have long been used in the world. Given that 
in the former Yugoslavia to the '90s production and use of ANFO explosives was neglected, its intensive use in mining in Bosnia and Herzegovina dated after 1996, since when it is produced by a larger number of companies. Like most other ANFO explo sives and ANFO explosives "RUDEX-1", which is produced on a mobile plant at the place of use, is one of the explosives with good blasting properties in particular because of its delayed action-suppression and reduced seismic impacts.

Table 4 Characteristics of ANFO explosives "RUDEX-1"

\begin{tabular}{||l|r|}
\hline Gas volumes $(1 / \mathrm{kg})$ & 1,039 \\
\hline Explosion temperature $\left({ }^{0} \mathrm{C}\right)$ & 1,791 \\
\hline Explosion energy $(\mathrm{kJ} / \mathrm{kg})$ & $3,786.85$ \\
\hline Explosive power $\left(\mathrm{J} / \mathrm{m}^{2} \mathrm{~s}\right)$ & $2.59 \times 10^{10}$ \\
\hline Detonation transmission $(\mathrm{cm})$ & Contact \\
\hline Density $(\mathrm{kg} / \mathrm{l})$ & $0.836-0.883$ \\
\hline Detonation velocity $(\mathrm{m} / \mathrm{s})$ & 3,300 \\
\hline Water resistance & Weak \\
\hline Maximum turning diameter $(\mathrm{mm})$ & $>50$ \\
\hline
\end{tabular}

\section{Identifying problematic mixtures of ANFO explosives}

There are visual indications whether the detonation and the release of energy is good or not. When it releases vapors colored light gray, oxygen balance is almost perfect and maximum energy is released. When gases are colored in yellow or rust color they show that the response was not effective; it may be due to an excess of oxygen in the mixture. If there is a lack of oxygen in the mix, it creates a dark gray gas, and often on the rock bores leaves carbon. All commercial explosives should have balanced oxygen. So, after detonation, the products of an ideal reaction should form only a light gray fume. Unfortunately, on the sites, it is not uncommon to see other colors puffs after the reaction is completed. Whenever there are, after explosion, the colored fumes imply that the reaction of explosives was not effective, and that a part of useful energy is lost. The problem must be solved immediately otherwise; it may result in a hazardous condition when mining. If there is not enough released energy, there will not be enough energy in the hole to the appropriate crushed material around the blast hole. Blast holes are filled with insufficient means for the existing characteristics of rocks being dispersed. They also cause ground vibrations higher than normal, without the material behind the hole being dispersed, with the possibility of not crushing to the desired depth. Practically, performing mass controlled mining with a dominant use of ANFO explosives "RUDEX 1" was performed in 2006 and 2007 for the construction the first section of the highway Podlugovi to Josanice in Sarajevo and the scond line from Podlugovi to Visoko. Drilling-blasting and other parameters of a typical mass blasting are given in the Appendix. 


\section{SKICA MINSKOG POLJA}

MINIRANJE BROJ: ..........DANA: 12,07.2007. god.

ETAŽA: ...565...VRIJEME: ...14 sati...PORUŠENO STIJENE: Q=9.421 $\mathbf{m}]^{7}$ SKICA MINSKOG POUA: DUŽINA...95,65 m..., ŠIRINA...9,80 m
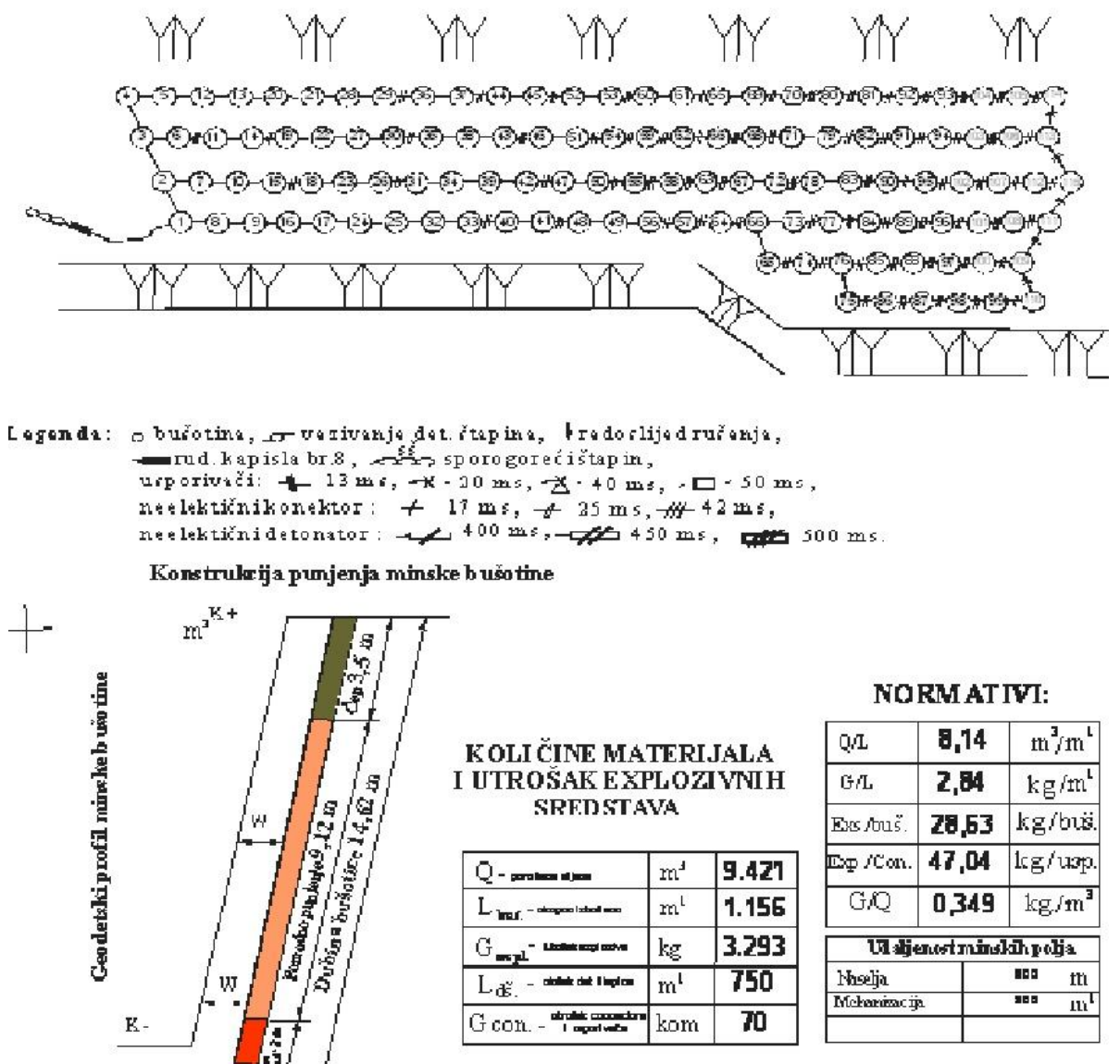

\section{LEGEIYDA :}

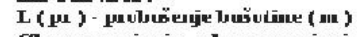

Glavno punjegie - plavno punjenje brizantmi exploriv (m)

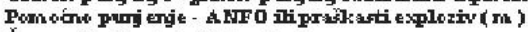

Cep - $r$ iseplienje butiotine ( $\mathrm{m}$ )

Figure 5 Mass drilling-blasting parameters

\section{DISCUSSIONS}

Until the beginning of its own production the ANFO explosives on the mobile plant the process of blasting operations, the explosives of various suppliers were used. The results of mining in the field with these explosives were various, which is reflected 
in the increased participation of oversized particle size $(800-900 \mathrm{~mm})$. Adopting the technology of ANFO explosives in mobile systems and controlling the quality of manufactured explosive mixture in the field has noted the significant improvements in the quality of realized blasting (grit reached $450-500 \mathrm{~mm}$ ). Controlling the quality of ANFO explosives and the use of it has also enabled a correction of drilling-blasting parameters from GRP at:

- A - distance between the bores in a row $-3.40 \mathrm{~m}$

- B - spacing between the bores $-2.80 \mathrm{~m}$

- W - the least resistance line $-3.0 \mathrm{~m}$

This has finally resulted in better economic indicators derived from mining or savings cca. $10 \%$.

\section{FINAL CONSIDERATIONS}

Using the quality technical ammonium nitrate $A N$ as the basic raw material in the manufacture of ANFO explosives in addition to optimal amounts of oil (FO) and proper mixing, the assumption is to get good ANFO explosives. Applying so produced ANFO explosives in a dry and semi-dry work environments with expert definition of drilling-blasting parameters (geometry drilling), gives the excellent results in the blasting of medium, hard and hard working environment, as it is present in the material.

Due to the limit diameter of blasting the blast hole with ANFO explosives larger than $50 \mathrm{~mm}$, its use for blasting in dry boreholes with diameter of $76 \mathrm{~mm}$ in bulk yielded remarkable results, in terms of specific consumption of the same as obtained by granulation the materials mined. The results, derived from mass blasting at the "RKB" Breza, suggest the possibility of managing the same as the object of all blasting.
The result is an average grain size of blasted material in large quantities of limestone from $500 \mathrm{~mm}$ with oversize granules of (3-5)\% with minimal seismic impacts on people and objects in the immediate environment, indicating a serious and disciplined approach to blasting in particular object, especially due to the fact that there is a reservoir of heterogeneous structure of stone, which is harder to bring in the necessary equality of seismic impedance in the working environment and used explosives.

The fact that the laws of the Federation of Bosnia and Herzegovina warrant the production of ANFO explosives in the place of use, provides the increased security measures due to the reduced distribution of explosives in public transport, or only the initial explosives enhancers (busters) and supporting blasting-explosive agents (detonating cords and safety fuses, mining caps no.8, electric lighters-detonators, detonators and Nonel retardants (connectors)) are distributed in public transport

\section{REFERENCES}

[1] B. Bozic, Blasting in mining, Construction and Geotechnical Engineering, Varazdin 1998 (in Serbian);

[2] The Main Mining Design of Exploitation the Construction Stone in the Deposit Nedici Near Breza, Rudex Ltd., 2000 (in Serbian);

[3] Blasting Plan and Drafts 2007, RUDEX Ltd., (in Serbian);

[4] M. Antunovic-Kobliska, General Mining Operations, Belgrade, 1973 (in Serbian);

[5] S. Trajkovic, S. Slimák, S. Lutovac, The Technique of Blasting and Earthquakes, University of Belgrade, Faculty of Mining and Geology, Belgrade, 2005 (in Serbian). 


\begin{tabular}{ll}
\hline \hline INSTITUT ZA RUDARSTVO I METALURGIJU BOR & ISSN: 2334-8836 \\
& UDK: 622 \\
\hline \hline
\end{tabular}

\section{IZVOĐENJE MASOVNIH KONTROLISANIH MINIRANJA NA „RUDNIKU KREČNJAKA BREZA“, BREZA, UZ DOMINANTNO KORIŠTENJE ANFO EKSPLOZIVA „RUDEX - 1““}

\section{Izvod}

ANFO eksplozivi u većini slučajeva učestvuju sa $90 \%$ u ukupnoj masi eksploziva prilikom izvođenja masovnih miniranja na rudarsko-građevinskim objektima na teritoriju Bosne i Hercegovine. Veći broj domaćih bušačko-minerskih firmi koristi ANFO eksplozive vlastite proizvodnje (proizvodnja "in situ" odnosno sa mobilnim postrojenjem na mjestu upotrebe). Ovaj rad tretira iskustva firme „,Rudex,, d.o.o. - Sarajevo, u projektovanju i izvođenju masovnih bušačko-minerskih radova na kamenolomu krečnjaka „RKB,,, sa dominantnom upotrebom ANFO eksploziva (Rudex-1).

Ključne riječi: miniranje, ANFO, kamenolom RKB, bušačko-minerski parametri

\section{UVOD}

Na ležištu krečnjaka „Nedići“, privredno Društvo „Rudnik krečnjaka Breza“ d.o.o. Breza, vrši eksploataciju građevinskog kamena krečnjaka od 2000-te godine. Ležište je otvoreno na desnoj obali rijeke Stavnje, na udaljenosti od $2 \mathrm{~km}$ sjeve- roistočno od Breze, odnosno $27 \mathrm{~km}$ od Sarajeva, neposredno uz putnu saobraćajnicu: Sarajevo - Breza - Vareš. Ograničeni istražni i eksploatacioni prostor pruža se desnom padinom Stavnje, zvanom Dobra strana pravcem sjever-jug.

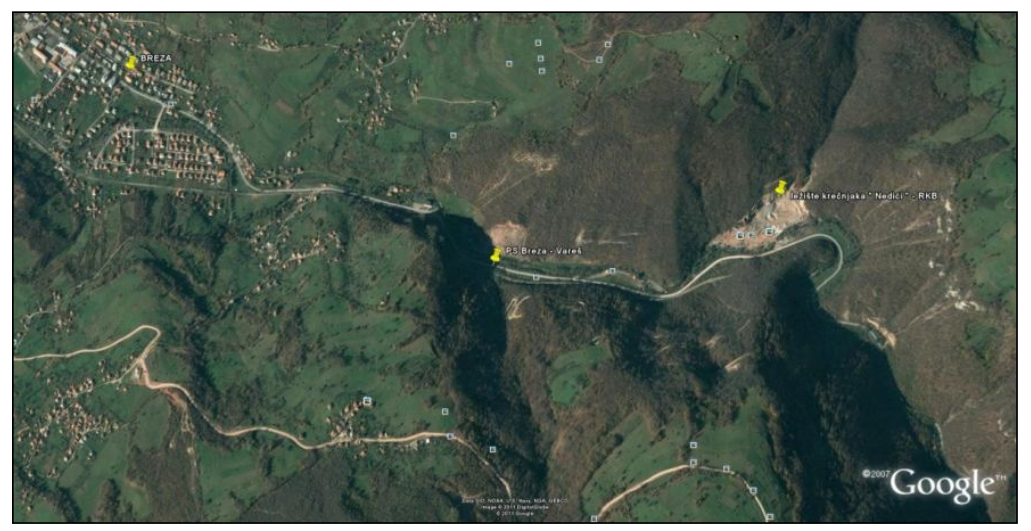

SI. 1. Geografski položaj ležišta „,Nedići,, - RKB d.o.o.,Breza

\footnotetext{
* "RUDEX" Ltd Sarajevo, BiH

** “STUDENTSKI BIRO 99" Ltd Tuzla, BiH

*** "INZIO" Ltd., Tuzla, BiH
} 
Krečnjaci ovog ležišta pripadaju sedimentnim sivim klasičnim karbonatnim stijenama uslojenim i bankovitim, a $\mathrm{u}$ petrografskom smislu radi se o kalkarenitima sa sadržajem $\mathrm{CaCO}_{3}$ od $95 \%$, zapreminska težina $(\gamma)$ krečnjaka kreće se oko $2800 \mathrm{~kg} / \mathrm{m}^{3}$ č.m. Čvrstoća na pritisak ispitanih uzoraka u suhom stanju kreće se oko $160 \mathrm{MPa}$, dok se čvrstoća na pritisak ispitanih uzoraka u vodozasićenom stanju kreće oko $133 \mathrm{MPa}$.

\section{PARAMETRI MINERSKIH RADOVA NA RUDNIKU KREČNJAKA BREZA}

Glavnim rudarskim projektom eksploatacije krečnjaka definisani su bušačkominerski parametri kako slijedi:

- promjer bušenja minskih bušotina(Ø) $-76 \mathrm{~mm}$,
- visina etaža h=10 m', optimalni gabarit odminiranog kamena $600 \mathrm{~mm}$,

- linija najmanjeg otpora (n) 2,7 m, razmak između bušotina u redu (a) $3,5 \mathrm{~m}$,

- razmak između redova bušotina (b) 3,2 m, dužina čepa 2,7 m',

- specifična potrošnja eksploziva (q) $0,34 \mathrm{~kg} / \mathrm{m}^{3}$ č.m.,

- procentualno učešće inicijalnih plastičnih eksploziva u miniranjima oko 5\%, procentualno učešće ANFO eksploziva u miniranjima je oko $95 \%$,

- ukupna količina eksploziva po bušotini $30,5 \mathrm{~kg}$,

- maksimalna definirana količina eksploziva po minskom polju iznosi $1.000 \mathrm{~kg} \mathrm{uz}$ preporuku korištenja milisekundnih usporivača.

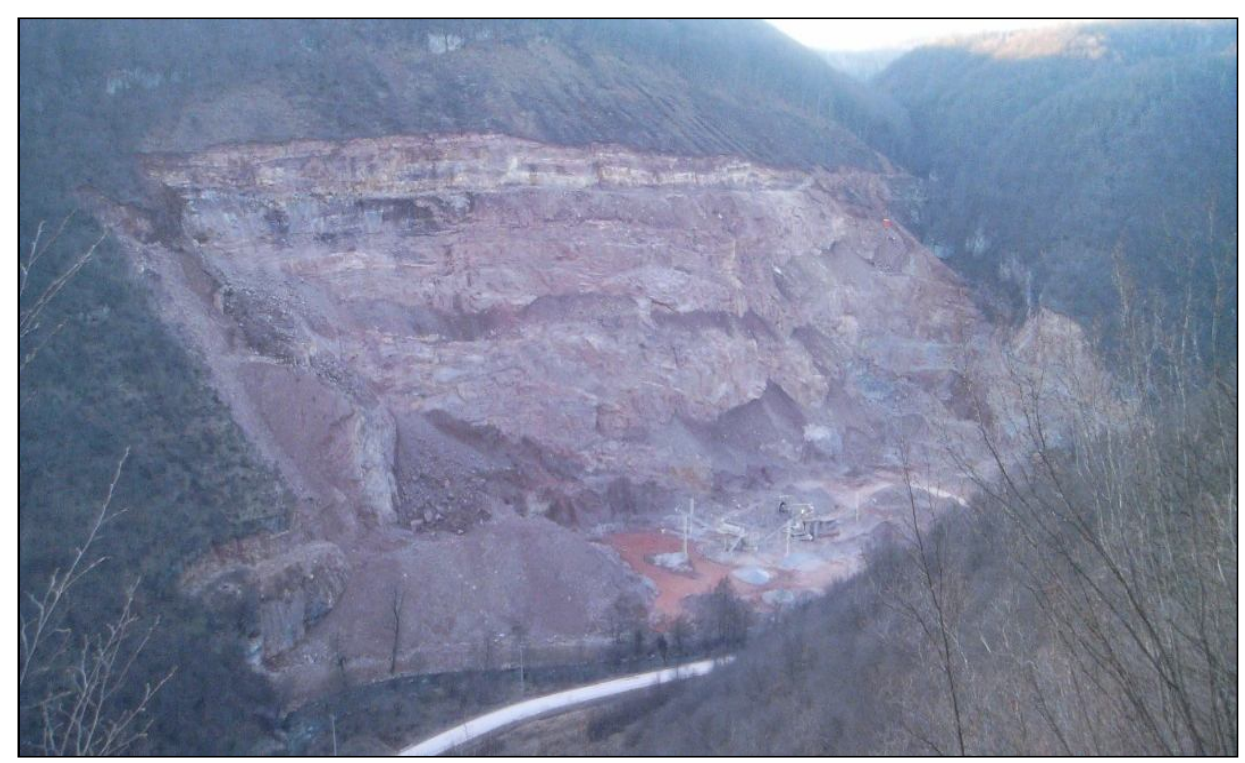

Sl. 2. Panorama terena i kamenoloma krečnjaka „Nedići,, u dolini Stavnje

U toku procesa miniranja nastaju određene vrste energija koje se generalno mogu klasificirati u: a) korisne energije $\mathrm{i}$

b) beskorisne energije. 


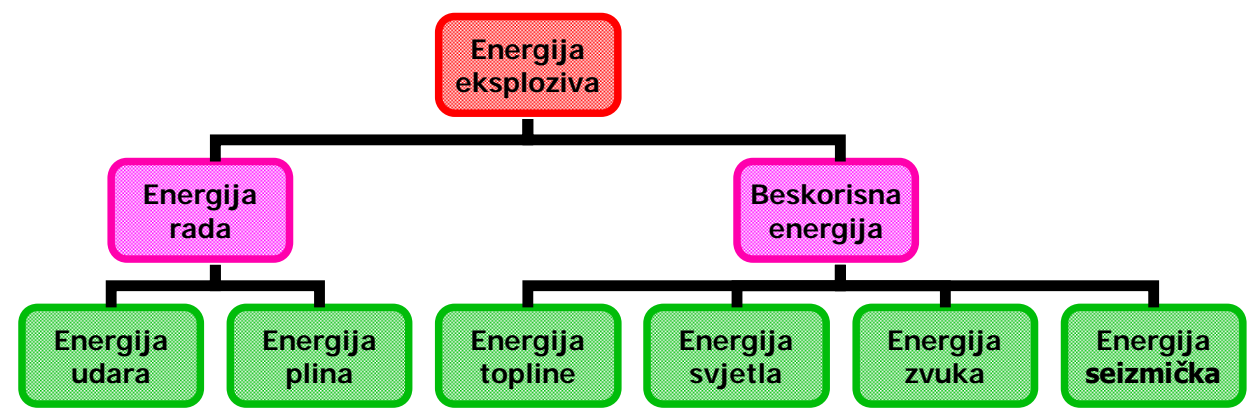

SI. 3. Šematski prikaz vrsta energija nastalih prilikom procesa eksplozije

Dva su korisna tipa energije koja nastaju prilikom hemijske reakcije razgradnje eksploziva čija je rezultanta - korisni izvršeni rad.

\section{Prvi tip energije naziva se energija udara}

Prilikom hemijskog razlaganja eksploziva odnosno njegove detonacije dolazi do stvaranja jakog pritiska koji se manifestuje kroz energiju udara na stijensku masu. Pritisak izazvan detonacijom je u funkciji gustoće eksploziva umnožen kvadratom brzine reakcije eksploziva (detonacije), što čini oblik kinetičke energije. Pritisak detonacije je pritisak koji vrši detonacioni val koji se širi kroz stub eksploziva. Detonacioni pritisak bice maksimalan u patroni eksploziva na suprotnom kraju od onog gdje je bilo iniciranje. Pritisak deto-nacije na stranama patrona je skoro nula jer se detonacioni val ne širi prema ivicama patrone.

\section{Drugi tip energije naziva se energija plina}

Energija plina oslobađa se $\mathrm{u}$ toku procesa detonacije i prouzrokuje veći dio lomljenja stijena prilikom miniranja $u$ zatvorenim bušotinama. Zato su definiranje optimalne dužine čepa minske bušotine i izbor odgovarajućeg inertnog materijala za formiranje čepa vrlo važni u miniranju. Pritisak plina često nazvan i pritisak eksplozije je pritisak koji na stjenke bušotine vrše ekspandirajući plinovi nakon što je završena hemijska reakcija. Veličina pritiska eksplozije zavisi od volumena plinova oslobođenih po jedinici težine eksploziva i količini toplote koja se oslobađa u toku reakcije.

\section{Treći tip energije naziva se beskorisna energija}

Kao što joj i samo ime govori predstavlja, odnosno rezultat je dobijanja negativnih nusprodukata prilikom razvoja hemijske reakcije, odnosno razgradnje eksploziva na: energiju topline, energiju svjetla, energiju zvuka i energiju seizmike - seizmičkog uticaja na objekte i živa bića u neposrednoj okolini gdje se izvode miniranja.

\section{EKSPLOZIVNI SASTOJCI U EKSPLOZIVIMA}

Odgovarajući odnosi eksplozivnih sastojaka u eksplozivima predstavljaju osnovu za provedbu uspješne - kvalitetne hemijske reakcije u eksplozivima, koja za posljedicu treba da obezbijedi u maksimalnom procentu razgradnju istog prvenstveno u energiju udara i energiju plina, kao energije rada, a u minimalnom procentu proizvodnje beskorisnih energija: topline, svjetla, zvuka i seizmičke energije. Sastavni elementi u eksplozivima se uopšteno smatraju elementima goriva ili oksidirajućim elementima i prikazani su u slijedećoj tabeli: 
Tabela 1. Sastavni elementi u eksplozivima

\begin{tabular}{|c|c|c|}
\hline Sastojak & Hemijska formula & Funkcija \\
\hline \hline Nitroglicerin & $\mathrm{C}_{3} \mathrm{H}_{5} \mathrm{O}_{9} \mathrm{~N}_{3}$ & eksplozivna osnova \\
\hline Nitroceluloza & $\mathrm{C}_{6} \mathrm{H}_{7} \mathrm{O}_{11} \mathrm{~N}_{3}$ & eksplozivna osnova \\
\hline Trinitrotoluol (TNT) & $\mathrm{C}_{7} \mathrm{H}_{5} \mathrm{O}_{6} \mathrm{~N}_{3}$ & eksplozivna osnova \\
\hline Amonijumnitrat & $\mathrm{H}_{4} \mathrm{O}_{3} \mathrm{~N}_{2}$ & nosilac kisika \\
\hline Natrijnitrat & $\mathrm{NaNO}_{3}$ & nosilac kisika \\
\hline Nafta & $\mathrm{CH}_{3}$ & gorivo \\
\hline Drvena pulpa & $\mathrm{C}_{6} \mathrm{H}_{10} \mathrm{O}_{5}$ & gorivo \\
\hline Ugljik & $\mathrm{C}$ & gorivo \\
\hline Aluminijski prah & $\mathrm{Al}$ & pojačivač goriva \\
\hline Krečnjak-kreda & $\mathrm{CaCO}$ & neutralizator kiseline \\
\hline Cinkoksid & $\mathrm{ZnO}$ & neutralizator kiseline \\
\hline Natrijhlorid & $\mathrm{NaCl}$ & potiskuje plamen \\
\hline
\end{tabular}

Gotovo svi eksplozivi upotrebljavaju kisik kao oksidirajući element. Može se koristiti Zakon za idealne plinove kao prva aproksimacija za određivanje pritiska koji nastaje u reakciji eksploziva:

$$
P \cdot V=N \cdot R \cdot T
$$

gdje je:

$$
\begin{aligned}
& \mathrm{N}=\text { moli plina, } \\
& \mathrm{P}=\text { pritisak, } \\
& \mathrm{V}=\text { volumen }, \\
& \mathrm{R}=\text { plinska konstanta } \mathrm{i} \\
& \mathrm{T}=\text { apsolutna temperatura }
\end{aligned}
$$

Eksplozivne reakcije ne ponašaju se idealno, kao što se pretpostavlja ovom jednadžbom, jer su pritisci ekstremno visoki, pa se moraju koristiti korektivni faktori za pretpostavljanje ponašanja plinova na visokim pritiscima. Vjerovatno je najjednostavniji način za shvatanje i korištenje faktora korekcije upotrebom formule:

$$
P \cdot V=Z \cdot N \cdot R \cdot T
$$

gdje je: $Z$ = faktor stišljivosti

Faktor stišljivosti (Z) dobije se sa krivulja, što traži poznavanje reduciranih temperatura i reduciranog pritiska što dolazi od plina. Kod proizvodnje eksploziva izuzetno se vodi računa o uravnoteženju goriva i kisika da bi se izbjegao manjak, kao i višak kisika. Nedostatak kisika vodio bi do niskog oslobađanja energije, do sporog oslobađanja energije, do razlike $\mathrm{u}$ broju malih molekula, do niže temperature time i do nižeg pritiska. Višak kisika vodio bi ekstremnoj osjetljivosti, oslobađanju manje energije i stvaranja štetnih i otrovnih oksida

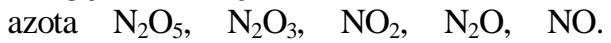
Amonijum-nitrat (AN) ima formulu $\mathrm{NH}_{4} \mathrm{NO}_{3}$ što pokazuje sastojke i njihovu vezu. Pišući na drugi način formulu dobija se $\mathrm{N}_{2} \mathrm{H}_{2} \mathrm{O}_{3}$, a u obliku slijedeće tabele:

Tabela 2. Bilans goriva i kiseonika

\begin{tabular}{|c||c||c||}
\hline \hline Element & Željeni proizvod reakcije & Potreban kisik \\
\hline \hline $\mathrm{N}_{2}$ & $\mathrm{~N}_{2}$ & nijedan \\
\hline $\mathrm{H}_{4}$ & $2 \mathrm{H}_{2} \mathrm{O}$ & 2 \\
\hline $\mathrm{O}_{3}$ & nijedan & nijedan \\
\hline
\end{tabular}

manjak ili višak $3-2=1$ (višak kisika) 
Nafta se dodaje uz AN da osigura potrebno gorivo. Nafta (FO) može za ove svrhe imati formulu $\mathrm{CH}_{2}$. Ako se $\mathrm{CH}_{2}$ piše u obliku tabele:

Tabela 3. Hemijska reakcija oksidacije

\begin{tabular}{|c|c|c||}
\hline Element & Željeni proizvod reakcije & Potreban kisik \\
\hline \hline $\mathrm{C}$ & $\mathrm{CO}_{2}$ & 2 \\
\hline $\mathrm{H}_{2}$ & $\mathrm{H}_{2} \mathrm{O}$ & 1 \\
\hline
\end{tabular}

Nula (0) - 3 (nedostatak kisika)

Rezultat je nedostatak kisika po jedinici $\mathrm{CH}_{2}$. Budući da AN ima 1 kisik, potrebne su tri jedinice AN da se uravnoteži jedna jedinica u ANFO smješi.

$$
3 \mathrm{AN}+1 \mathrm{FO} \mathrm{CO}_{2}+7 \mathrm{H}_{2} \mathrm{O}+3 \mathrm{~N}_{2}
$$

Iz ove balansirane reakcije vidi se da su potrebne tri molekularne težine amonijumnitrata i jedna molekularna težina nafte da se proizvede idealan plin o kome se ranije govorilo, za proizvodnju korisnog rada - rušenja stijene. $\mathrm{Na}$ slijedećoj slici dat je odnos gubitka energije amonijnitrata i nafte prema procentu nafte koji se dodaje u mješavinu. Teoretski optimalan bilans je 5,7\% nafte i $94,3 \%$ amonijumnitrata. Proizvođači normalno čine mješavinu sa $6 \%$ nafte. $\mathrm{Na}$ slici se vidi da kada opada sadržaj nafte ispod željenog $5,7 \%$ naglo opada oslobađanje energije. Ako oprema koja pravi smjesu nafte i amonijumnitrata nije precizna uvijek je bolje imati više nafte nego manje, zbog njenog isparavanja.

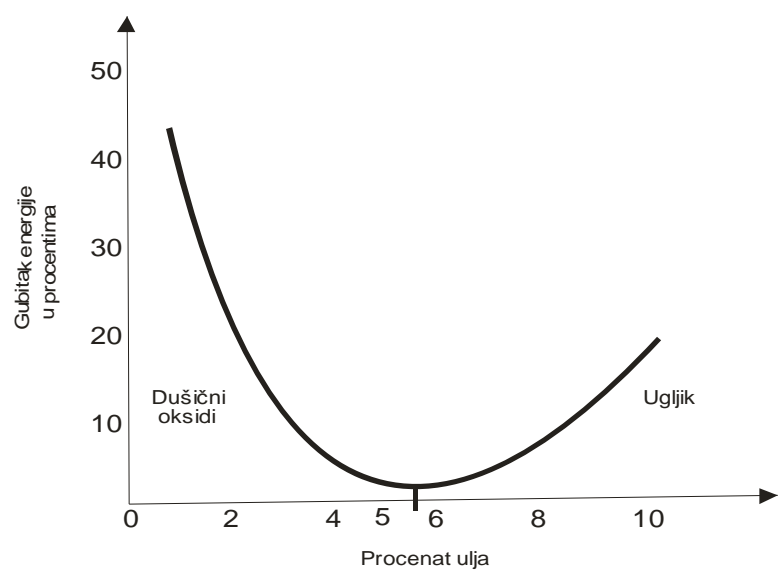

Sl. 4. Zavisnost gubitka energije od procentualnog učešća nafte u ANFO eksplozivima

\section{Proizvodnja i primjena ANFO eksploziva}

ANFO eksplozivi ili ANFO smješe nisu ništa novo niti spektakularno ni na ovim prostorima Jugoistočne Evrope, imajući u vidu njihov hemijski sastav i jednostavnost proizvodnje, jer se u minerskoj praksi u svijetu već dugo koriste. S obzirom da je na 
prostoru bivše Jugoslavije do 90-tih godina proizvodnja i upotreba ANFO eksploziva bila zapostavljena, njegovo intenzivno korištenje u miniranju u Bosni i Hercegovini datira poslije 1996 godine, od kada ga proizvodi veći broj firmi. Kao i većina ostalih ANFO eksploziva i ANFO eksploziv „Rudex-1“ koji se proizvodi na mobilnom postrojenju na mjestu upotrebe spada $u$ eksplozive sa dobrim minerskim svojstvima posebno zbog svog zakašnjelog dejstvapotiskivanja i smanjenog seizmičkog uticaja.

Tabela 4. Karakteristike ANFO eksploziva „Rudex-1“

\begin{tabular}{|l|r|}
\hline Zapremina plinova $(\mathrm{l} / \mathrm{kg})$ & 1.039 \\
\hline Temperatura eksplozije $\left({ }^{0} \mathrm{C}\right)$ & 1.791 \\
\hline Energija eksplozije $(\mathrm{kJ} / \mathrm{kg})$ & $3.786,85$ \\
\hline Brizantnost $\left(\mathrm{J} / \mathrm{m}^{2} \mathrm{~s}\right)$ & $2,59 \times 10^{10}$ \\
\hline Prenos detonacije $(\mathrm{cm})$ & Kontakt \\
\hline Gustoća $(\mathrm{kg} / \mathrm{l})$ & $0,836-0,883$ \\
\hline Brzina detonacije $(\mathrm{m} / \mathrm{s})$ & 3.300 \\
\hline Vodootpornost & slaba \\
\hline Minimalni radni prečnik $(\mathrm{mm})$ & $>50$ \\
\hline
\end{tabular}

\section{Prepoznavanje problematičnih mješavina ANFO eksploziva}

Postoje vizualne indikacije da li je detoniranje i oslobađanje energije dobro ili nije. Kada se oslobađa para obojena svijetlosivo, bilans kisika je gotovo idealan i oslobađa se maksimalna energija. Kada su plinovi obojeni u žuto ili bojom hrđe oni pokazuju da reakcija nije bila efikasna, što može biti zbog viška kisika u mješavini. Ako je manjak kisika u mješavini, stvaraju se tamnosivi plinovi, a često na stijenama bušotine ostavljaju ugljik. Svi komercijalni eksplozivi trebali bi imati bilansiran kisik. Zato nakon detonacije produkti idealne reakcije trebali bi formirati samo svijetlosive dimove. Nažalost, na radilištima nije neuobičajeno vidjeti druge boje dimova nakon što je reakcija izvršena. Kad god se nakon eksplozije vide obojeni dimovi znak je da reakcija eksploziva nije bila efikasna i da je dio korisne energije izgubljen. Problem se mora odmah riješiti jer inače može doći do opasnih stanja pri miniranju. Ako se ne oslobađa dovoljno energije, neće biti dovoljno energije $u$ bušotini da se odgovarajuće zdrobi materijal oko bušotine. Bušotine su znači nedovoljno punjene za postojeću karakteristiku stijene. Nedovoljno punjenje bušotina dovodi do zračnog udara i razbacivanja komada stijene. One također, prouzrokuju vibracije tla veće nego što je normalno, bez potrebe se drobi materijal iza bušotine, sa mogućnošću ne drobljenja do željene dubine. Praktično izvođenje masovnih kontroliranih miniranja sa dominantnim korištenjem ANFO eksploziva „Rudex 1“ vršeno je u toku 2006 i 2007 godine za potrebe izgradnje I (Prve) dionice auto puta od Podlugova do Jošanice kod Sarajeva kao i II (Druge) dionice od Podlugova do Visokog. Bušačko-minerski i drugi parametri jednog karakterističnog masovnog miniranja dati su u prilogu. 


\section{SKICA MINSKOG POLJA}

MINIRANJE BROJ: ...........DANA: 12.07.2007. god.

ETAŽA: ...565...VRIJEME: ...14 sati...PORUŠENO STIJENE: Q=9.421 $\mathrm{ll}^{7}$ SKICA MINSKOG POUA: DUŽINA...95,65 m..., ŠIRINA...9,80 m
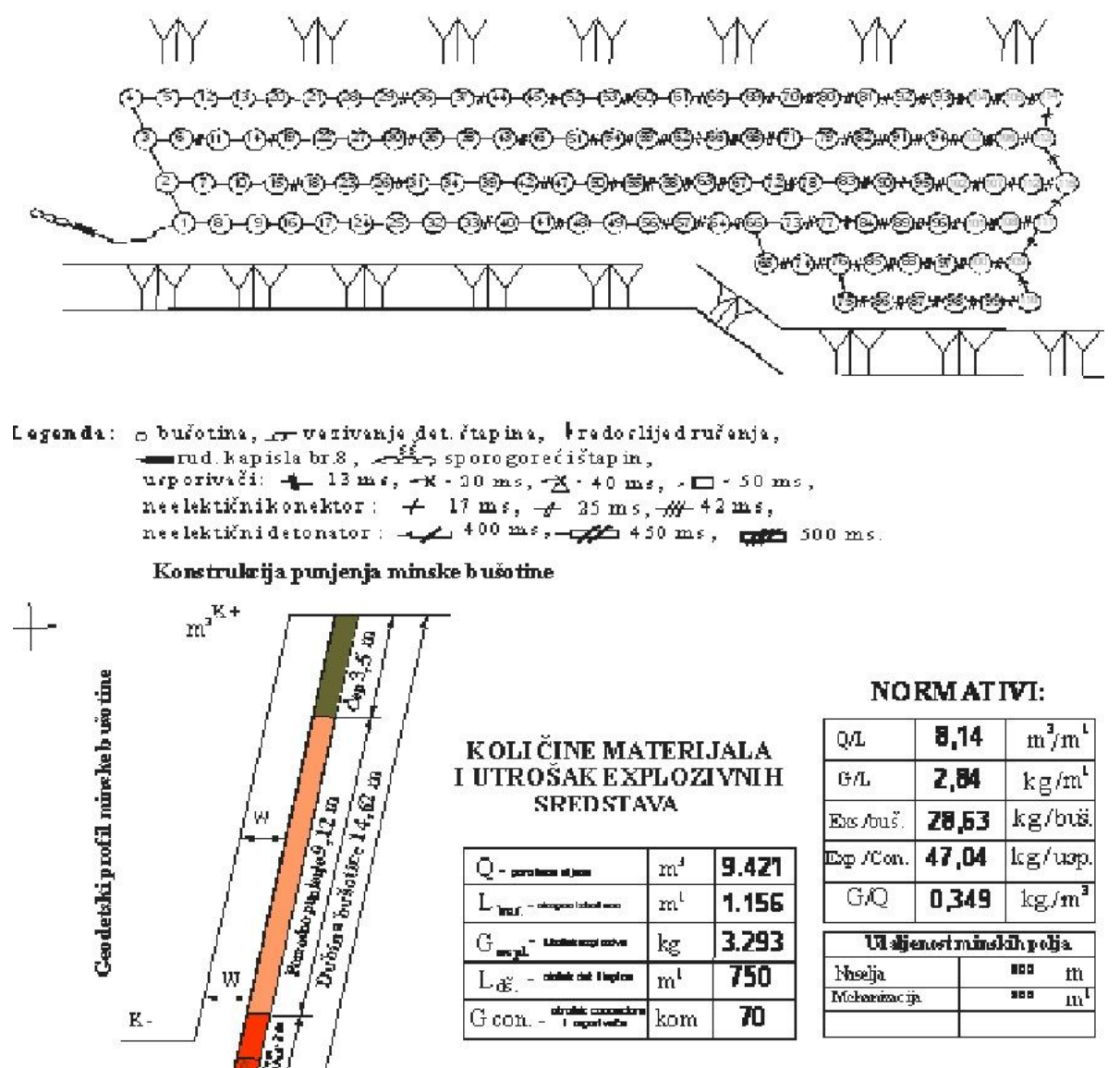

\section{IFGEDA}

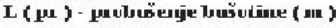

Glavno punjenje - glavno pumjenjebriranthi explariv (m)

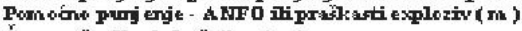

Cep - r iceplienje hutotine ( $\mathrm{m}$ )

\section{S1. 5. Bušačko-minerski parametri masovnog miniranja}

\section{RASPRAVA}

Do početka vlastite proizvodnje ANFO eksploziva na mobilnom postrojenju, u procesu izvođenja minerskih radova korišteni su eksplozivi raznih dobavljača. Rezultati miniranja na terenu sa ovakvim eksplozivima su bili vrlo šaroliki, što se 
reflektovalo na povećano učešće vangabaritne granulacije $(800$ - $900 \mathrm{~mm})$. Usvajanjem tehnologije proizvodnje ANFO eksploziva na mobilnom postrojenju i kontroliranjem kvaliteta proizvedene eksplozivne smješe, na terenu su zabilježena značajna poboljšanja u kvalitetu izvedenih miniranja (postignuta granulacija 450-500 $\mathrm{mm})$. Kontroliranje kvaliteta ANFO eksploziva i upotreba istog, omogućili su i korigovanje bušačko-minerskih parametara iz GRP-a na :

- A - razmak između bušotina u redu $-3,40 \mathrm{~m}$

- B - razmak između redova bušotina $-2,80 \mathrm{~m}$

- W - linija najmanjeg otpora $-3,0 \mathrm{~m}$

Ovo je u konačnici rezultiralo i boljim ekonomskim pokazateljima izvedenih miniranja odnosno uštedama od cca. $10 \%$.

\section{ZAKLJUČNA RAZMATRANJA}

Korištenje kvalitetnog tehničkog amonijum nitrata AN kao osnovne sirovine u proizvodnji ANFO eksploziva uz dodatak optimalne količine nafte (FO) i odgovarajuće miješanje, osnovna je pretpostavka da se dobije dobar ANFO eksploziv. Primjena tako proizvedenog ANFO eksploziva $u$ suhim i polusuhim radnim sredinama uz stručno definiranje bušačko-minerskih parametara (geometrije bušenja), daje izvanredne rezultate u miniranjima srednje tvrdih i tvrdih radnih sredina, kao što je prezentirano u materijalu.

S obzirom na utvrđeni granični prečnik miniranja minskih bušotina sa ANFO eksplozivom većim od $50 \mathrm{~mm}$, njegovo korištenje za miniranja u suhim bušotinama sa prečnikom od $76 \mathrm{~mm}$ u rinfuznom stanju dalo je izvanredne rezultate, s aspekta specifične potrošnje istog kao i dobivene granulacije odminiranog materijala.
Rezultati izvedenih masovnih miniranja na „RKB“ - Breza, ukazuju na mogućnost upravljanja istim što je osnovni cilj svih miniranja.

Dobivena prosječna granulacija zrna odminiranih većih količina krečnjaka od 500 mm sa nadzrnom od (3-5)\% uz minimalne seizmičke uticaje na ljude i objekte $u$ neposrednom okruženju ukazuje na ozbiljan $\mathrm{i}$ disciplinovan pristup miniranjima $u$ konkretnom objektu, posebno zbog činjenice da se radi o ležištu sa heterogenom strukturom kamena, gdje je teže dovoditi u potrebnu jednakost seizmičku impendancu radne sredine i eksploziva koji se koriste.

Činjenica da je propisima u Federaciji Bosne i Hercegovine dozvoljena proizvodnja ANFO eksploziva samo na mjestu upotrebe, obezbjeđuje povećane sigurnosne mjere, jer je smanjena distribucija eksploziva u javnom saobraćaju, odnosno $u$ javnom saobraćaju se distribuiraju $u$ najvećem slučaju samo inicijalni eksplozivi, pojačivači (busteri) i prateća minskoeksplozivna sredstva (detonirajući i sporogoreći štapini, rudarske kapisle br. 8, električni upaljači - detonatori, Nonel detonatori i Nonel usporivači (konektori)).

\section{LITERATURA}

[1] B. Božić, „Miniranje u rudarstvu, graditeljstvu i geotehnici“, Varaždin 1998. godine.

[2] Glavni rudarski projekat eksploatacije građevinskog kamena na ležištu „Nedići“ kod Breze, Rudex d.o.o., 2000 godina.

[3] Plan i skice miniranja 2007 godine, Rudex d.o.o., 2007 godina.

[4] M. Antunović-Kobliška "Opšti rudarski radovi", Beograd 1973. godine.

[5] S. Trajković, Š. Slimak, S. Lutovac, "Tehnika miniranja i potresi", Univerzitet u Beogradu, Rudarsko-geološki fakultet, Beograd 2005. godine 